\title{
THE USE OF NON-CONVENTIONAL SUPPLEMENTARY FEEDS IN CATTLE AND LAYER DIET
}

\section{ПРИМЕНЕНИЕ НЕТРАДИЦИОННЫХ КОРМОВЫХ ДОБАВОК В РАЦИОНАХ КРУПНОГО РОГАТОГО СКОТА И КУР-НЕСУШЕК}

\author{
IGNATOVICH, Larisa S. ${ }^{1 *}$; GINTER, Elena V. ${ }^{2}$; LYKOV, Aleksandr S. ${ }^{3}$; \\ KUZMINA, Irina $\mathrm{Yu}^{4}$; KUSTOVA, Svetlana B.; 5 \\ 1,2,3,4,5 Department of Fundamental Applied Studies and Innovative Researches, Magadan Agricultural Research \\ Institute, Magadan-685000, Russian Federation. \\ "Correspondence author \\ e-mail: lignatovich@rambler.ru
}

Received 22 May 2019; received in revised form 20 June 2019; accepted 05 July 2019

\section{RESUMO}

Foi realizado um estudo sobre os efeitos da introdução de novos suplementos alimentares vegetais não convencionais nas dietas de vacas leiteiras e galinhas poedeiras industriais. As plantas não são cultivadas para a sua produção, mas referem-se a culturas selvagens que crescem no habitat natural em quantidades suficientes. O objetivo da pesquisa foi determinar o efeito da introdução de suplementos alimentares vegetais não convencionais sobre as qualidades produtivas de vacas e galinhas poedeiras; qualidade dos produtos (leite, ovos); digestibilidade de nutrientes (uso) de poedeiras e funções reprodutivas de vacas; e para identificar a eficiência econômica do uso desses alimentos suplementares, alterando a taxa de conversão alimentar. A composição dos suplementos alimentares para as vacas incluiu a pele do mar, agulhas de pinheiro rastejantes, líquens. Suplementos alimentares, compostos por farinha de peles marinhas e culturas silvestres, foram introduzidos na dieta de galinhas poedeiras: arbustos de erva-de-são-joão ou rosebay, urtiga e agulhas de pinheiro-rasteiro. Os estudos foram conduzidos em empresas agrícolas. Os experimentos foram realizados em vacas Ayrshire e Holstein de diferentes períodos de lactação e em poedeiras Hisex White de diferentes idades e períodos produtivos. Regimes randomizados foram utilizados, incluindo 2-5 níveis de alimentação. Os grupos de vacas foram formados por método de pareamento; Galinhas poedeiras foram formadas para o agrupamento e foram mantidas em condições zoidióticas iguais. Durante a formação do grupo, não houve diferenças significativas no peso corporal e produtividade entre os grupos formados foram revelados $(P>0,05)$, o que indica a seleção correta de grupos para a pesquisa. Como resultado, as vacas melhoraram as funções reprodutivas, aumentaram a produção de leite, gordura do leite e conversão alimentar; as galinhas mostraram a intensificação dos processos metabólicos, contribuindo para o aumento da produtividade, conversão alimentar e qualidade dos ovos $(P<0,05)$, o que indica a efetividade do uso de novos suplementos alimentares.

Palavras-chave: Poedeiras Industriais, Vacas Leiteiras, Alimentos Suplementos Vegetais, Conversão Alimentar, Funções Reprodutivas.

\section{ABSTRACT}

It was undertook a number of studies on the effects of introducing new non-conventional vegetable supplementary feeds in the diets of dairy cows and industrial laying hens. Plants are not cultivated for their production, but they refer to wild crops growing in the natural habitat in sufficient quantities. The purpose of the research was to determine the effect of introducing non-conventional vegetable supplementary feeds on the productive qualities of cows and laying hens; quality of products (milk, eggs); nutrient digestibility (use) of laying hens and reproductive functions of cows; and to identify the economic efficiency of using these supplementary 
feeds by changing feed conversion ratio. The composition of supplementary feeds for cows included sea furbelow, creeping pine needles, lichens. Supplementary feeds consisting of sea furbelow flour and wild crops were introduced into the diet of laying hens: fireweed or rosebay willowherb, stinging nettle, and creeping pine needles. The studies were conducted at the agricultural enterprises. The experiments were performed on Ayrshire and Holstein cows of different lactation periods and the Hisex White laying hens of various age and productive periods. Randomized regimens were used, including 2-5 levels of feeding. The groups of cows were formed by the analog to pair matching method; laying hens were formed by the analog to group matching method and were kept in equal zoohygienic conditions. During group formation, no significant differences in body weight and productivity between the formed groups were revealed $(P>0.05)$, which indicates the correct selection of groups for the research. As a result, cows improved reproductive functions, increased milk yield, milk fat content and feed conversion; hens showed the intensification of metabolic processes, contributing to an increase in productivity, feed conversion and egg quality $(P<0.05)$, which indicates the effectiveness of using new supplementary feeds.

Keywords: Industrial Laying Hens, Dairy Cows, Vegetable Supplementary Feeds, Feed Conversion, Reproductive Functions.

\section{АННОТАЦИЯ}

Авторами был проведён ряд исследований по изучению влияния ввода в рационы коров молочного направления продуктивности и промышленных кур-несушек новых нетрадиционных кормовых добавок растительного происхождения. Растения для их изготовления не являются культурными, а относятся к дикоросам, произрастающим в природе в достаточно больших объёмах. Цель исследований: определение влияния ввода нетрадиционных кормовых добавок растительного происхождения на продуктивные качества коров и кур-несушек; качество производимой продукции (молока, яиц); переваримость (использование) питательных веществ корма организмом кур-несушек и воспроизводительные фрункции коров; а также выявление экономической эффрективности их применения за счёт изменения конверсии корма. В состав кормовых добавок для коров были включены бурые морские водоросли, хвоя стланика кедрового, лишайники. В рацион кур вводились добавки, состоящие из муки бурых морских водорослей, дикорастущих растительных ресурсов: иван-чая узколистного, крапивы двудомной, хвои стланика кедрового. Исследования проводились на базе сельскохозяйственных предприятий. На опыты были поставлены коровы айрширской и голштинской пород различных периодов лактации и куры-несушки кросса Хайсекс белый различных возрастных и продуктивных периодов. Были использованы рандомизированные схемы, включающие в себя 2-5 уровней кормления. Группы коров были сформированы по методу пар-аналогов; кур-несушек - группаналогов и содержались в равных зоогигиенических условиях. При формировании групп достоверных различий по живой массе и продуктивности между сформированными группами не выявлено (Р>0,05), что говорит о корректном подборе групп для проведения исследований. В результате у коров улучшились воспроизводительные функции, повысился удой, жирность молока и конверсия корма; у кур выявлена интенсификация обменных процессов, способствующая повышению продуктивности, конверсии корма и качества яиц $(\mathrm{P}<0,05)$, что свидетельствует об эффрективности применения новых кормовых добавок.

Ключевые слова: промышленные куры-несушки, коровы молочного направления продуктивности, кормовые добавки растительного происхождения, продуктивность, конверсия корма, воспроизводительные функции.

\section{INTRODUCTION}

Along with the task of fulfilling the genetic potential of the livestock productivity laid during the breeding works, agricultural producers face an important mission of creating conditions for the production of environmentally friendly products with improved consumer properties. Since virtually all the livestock can transfer nutrients required for human nutrition from combined fodder to the products, their quality and consumer properties may vary depending on the composition of rations. Through diets enriched with natural supplementary feeds, products with a higher concentration of biologically active substances can be obtained (Schöne et al., 2017, Opaliński 2017, Suray, 2010, Schöne and Rajendram, 2009). In our studies, the 
concentration of carotenoids in the egg yolk increased by $58 \%$, the iodine content in eggs became 8.6 times as high, and the conception rate of cows after the first insemination reached $80 \%$, which significantly exceeds the performance of similar studies.

The problem of improving the quality of rations can be solved by using new supplementary feeds from plant resources: sea furbelow (kelp - Laminaria), creeping pine needles (Pinus pumila), lichens (gray reindeer lichen - Cladonia alpestris, Iceland moss Cetraria islandica), fireweed (Chamaenerion angustifolium L.), and stinging nettle (Urtica dioica). All these components contain a wide range of biologically active substances and can be applied both in pure form and in the form of complex supplementary feeds. The novelty of livestock diets enriched with the abovementioned supplementary feeds lies in the fact that all their components belong among wild crops and do not require significant costs for their conservation and preparation for feeding.

Natural feed materials from wild plant resources can be used as an alternative to traditional synthetic antibiotics, which has recently become quite relevant. Antibiotics were used for therapeutic and prophylactic purposes and as a stimulator of growth and productivity when feeding livestock in the latter half of the $20^{\text {th }}$ century (Gustafson and Bowen, 1997). Using them to kill microorganisms or suppress their proliferation in a host organism can lead to changes in the immune system development of this organism (Schokker et al., 2017, Mulder et al., 2011, Mulder et al., 2009). Regular and excessive use of synthetic antibiotics leads to enhanced bacterial resistance. This bacterial resistance interferes with the treatment of both animals and humans since antibiotic resistance genes can be transmitted. Excessive or improper use of synthetic antibiotics in livestock husbandry leads to their accumulation in hyperadmissible quantities in food staples (including crop production after fertilizing the land with poultry litter), which poses a threat to human health, causing dysbiosis, allergies, and a decrease IN immunity (Goryacheva, 2013). At the end of the $20^{\text {th }}$ century, a campaign was launched to limit the use of synthetic antibiotics in Europe, which is due to the fact that product quality and its environmental safety are becoming increasingly important.

The use of synthetic antibiotics (AGP) as prophylactic doses in fodder was banned within some jurisdictions, such as in the European
Union (the EU Regulation, No. 1831/2003). An outright AGP ban was introduced in Europe in 2006 due to a growing public concern. Meanwhile, this ban became a global trend with many countries outside the European Union being on their way to restricting or banning their use in animal feed (Steiner and Syed, 2015; Niewold, 2007). Thus, there is a need to find alternatives to synthetic antibiotics to maintain the intestinal ecosystem balance, as well as to improve the overall livestock productivity. In order to solve these problems across the world, including Russia, there was an intensive search for means to do so (Huyghebaert et al., 2011; Goryacheva, 2013; Tajodini et al., 2015).

In this regard, interest has increased in studying the use of natural plant (phytogenic or botanical) additives in diets that contain a biocomplex that makes it possible to obtain environmentally friendly products that would not trigger a large number of "drug diseases" arising after treatment, including transmitted through egg, milk and meat (Dedkova and Avdyukhin, 2007; Hafeez et al., 2016; Moubayed et al., 2017; Bate et al., 2018).

\section{Earlier studies of vegetable stock showed} that non-conventional phytogenic ration ingredients possessed antimicrobial, antioxidant, and anti-inflammatory properties (Windisch et al., 2008; Gheisar and Kim, 2017). In addition, they had a stimulating effect on the digestive system by enhancing the secretion of digestive enzymes and increasing the feed conversion efficiency as a result of liver function improvement (Hernandez et al., 2004, Prakash and Srinivasan, 2010, Abou-Elkhair et al., 2014).

In Laminaria, antibiotic, growth-promoting, and medicinal substances are found, with a high biological activity that is often a sequence higher than the respective content of substances derived from terrestrial plants and animals; they are characterized by a chemical structure that is unparalleled with compounds derived from terrestrial organisms. Historically, Laminaria was used to treat various infectious diseases; in recent years, many studies were conducted on its biological activity, which confirmed its effect on the body. It is a rich source of natural antioxidants; their inhibitory activity against the lipoxygenase enzyme that oxidizes unsaturated fatty acids that make up the cereal plants of the livestock diet is their feature (Starikova, 2005; Matanjun et al., 2008; Zhao et al., 2008; AlAmoudi et al., 2009; Abdu-llah Al-Saif et al., 2014; Balina et al., 2016; Moubayed et al., 2017). 
Urtica dioica that contains a wide range of biologically active substances in a readily available form is used in a number of countries as an alternative to feed antibiotics, which does not have negative effects on the body and contributes to improved immunity and productivity (Rabazanov, 2003; Egorov, 2014; Meimandipour et al., 2017).

Pinus pumila contains effective and safe antibacterial components, which makes it suitable for processing into antiseptic preparations to antisepticise food and fodder products and for medical use. Pinus pumila exhibits antioxidant activity, the ability to remove free radicals and to inhibit oxidative damage to the DNA and body cells (Lantto et al., 2009; Feng et al., 2010; Zeng et al., 2014).

The first Russian antibiotic, the sodium salt of Usnic acid, was derived from Lichens; referred to as "Binan", it is recommended for use in veterinary medicine. Its bacteriostatic effect manifests in relation to Staphylococcus aureus, streptococci, anaerobes, pneumococci and tubercle bacilli (Müller, 2001; Podterob, 2008; Freysdottir et al., 2008; Bate et al., 2018).

Numerous observations show that antibiotics and phytobiotics that are part of the plant components are effective as a powerful factor stimulating the growth and development of animals and have a positive effect on the immune system, nutrient absorption, product quality, fatty acid composition and oxidative stability of muscles. The stimulating effect of these components on the feed intake is conditioned by its improved organoleptic indicators (taste and smell), which also leads to an increase in the livestock productivity (Saki et al., 2014; Gheisar and Kim, 2017).

\section{MATERIALS AND METHODS}

2.1. Biologically active substances that are part of plant materials: Laminaria, Pinus pumila, Cladonia alpestris, Cetraria islandica, Chamaenerion Angustifolium L., and Urtica dioica.

The composition of supplementary feeds derived from non-conventional plant sources includes a wide range of biologically active substances required for the vital activity of livestock and having a beneficial effect on metabolic processes, the immune system, the productivity, and the quality of products since they are in non-antagonistic combinations (Table 1).

Amino acids are the basic structural units of protein molecules. To ensure amino acids in a diet, it is necessary to include components containing a complete protein with essential amino acids. Limited availability of fish meal and whey protein concentrate in livestock diets has a negative impact on the total feed cost. Enriching the diet with amino acids that are part of natural plant components to activate the immune system allows one to replace expensive protein supplements and reduce feed cost in agricultural production (Goodband et al., 2014; Zhao et al., 2014).

The issue of supplying ruminants, including cattle, with amino acids is solved by intake of any protein and even non-protein nitrogenous matters. For a complete provision of laying hens, it is necessary to normalize their diet in terms of the content of 12 essential amino acids that are available and are used to perform a variety of functions (Lemesheva, 2006). The proteins in the components of the plants under study, namely, Laminaria (Starikova, 2005; Bazes et al., 2009), Urtica dioica and Chamaenerion angustifolium L. (Rabazanov, 2003; Egorov, 2014), and Pinus pumila (Rogachev and Salakhutdinov, 2015) contain a wide range of amino acids, including all the essential ones. Amino acids actively influence all the vital functions in the body of cattle and hens, such as the formation of structural and protective tissues and metabolic control. They play the role of precursors of many important non-protein constituents in the body and affect the productive and reproductive functions (Gonzalez-Esquerra and Leeson, 2001; Starikova, 2005).

Vitamins that are part of plant resources are high-molecular-weight organic compounds of varying chemical nature with high biological activity. They are nutritional factors that ensure a normal course of biochemical and physiological processes by participating in the metabolic control of the whole body. A lack of vitamins leads to impaired functioning of its various systems.

Algae, including Laminaria, contain a large amount of vitamins $C, D, E, K$, vitamin $B$ complex, and provitamin A (carotene). Biologically active substances rare in nature, such as taurine, citrulline, chondrin, and their compounds, which play an important role in the metabolic processes, were found in them (Starikova, 2005; Sharvadze et al., 2009; Makkar et al., 2016; Madeira et al., 2017).

Vitamins $\mathrm{C}, \mathrm{H}, \mathrm{E}, \mathrm{K}$, vitamin B complex, and provitamin A were found in Urtica dioica and Chamaenerion angustifolium L.. Introduction of 
grass flour and Urtica dioica flour into diets increases the accumulation of vitamin $C$ in the liver and adrenal glands and the respective accumulation of vitamin $A$ in these organs. Carotene is found in several forms in such flours, whereby $\beta$-carotene is the most active $(68-83 \%$ of the total carotenoids), since it forms two molecules of vitamin $A$, while the other forms form only one. The author is aware of the opinion of scientists and practitioners about the so-called "grass flour factor" that consists of healing properties of herbs (Rabazanov, 2003; Yegorov, 2014).

Pinus pumila contains a wide range of active substances; it is a supplier of carotene, vitamin B complex, vitamin C, and sterols (sources of vitamin D). Its needles contain chlorophyll and xanthophyll that play an important role in the metabolic processes, as well as a significant amount of phytoncides that protect the body from intestinal diseases. Terpenoids contained in Pinus pumila are called "atmospheric vitamins of the forest", since they activate enzymes in the body and are intermediate components in the biosynthesis of vitamins, steroids, and enzymes. Pinus pumila has long been used in traditional Chinese medical practice to treat various diseases since it possesses antibacterial and antiseptic properties, among others (Starikova, 2005; Lantto et al., 2009; Feng et al., 2010; Zeng et al., 2014; Rogachev and Salakhutdinov, 2015).

Lichenes are a rich source of vitamins $B_{12}$ and $C$ essential for the vital activity of an animal. It was found that anemia can develop and productivity can decrease with a deficiency of vitamin $B_{12}$. Some polysaccharides contained in Lichens enhance the production of nitrous oxide by macrophages and change the levels of production of anti-inflammatory cytokines by macrophages and dendritic cells. They can induce immunomodulatory reactions in macrophages and dendritic cells due to the antioxidant, antimicrobial, and antitumor activity of some major metabolites. Due to a high content of various biological substances, Lichens have practical application in medicine, including as sources of medicinal substances (Ingolfsdottir et al., 1994; Manojlović et al., 2012; Shrestha et al., 2015; Bate et al., 2018).

It was proved that the presence of vitamins $C$ and $E$ in the ration plant ingredients under study have a synergistic effect of biologically active substances; the function of one is important for effective action of another. The antioxidant function of fat-soluble vitamin $E$ and water-soluble vitamin C can prevent the production of oxidative substances in the liver, blood, and ovarian follicular fluid by increasing the amount of glutathione peroxidase, an enzyme that protects tissues from oxidative damage, removing peroxides that convert to free radicals, especially in thermal stress. Tocopherol has a positive effect on both the antibody-mediated and cell-mediated immune response of poultry (Pompeu et al., 2008; Dobbelaar et al., 2010; Steinberg and Rucker, 2013; Engelking, 2015; Surai et al., 2016; Schäfers et al., 2018).

Vitamin $\mathrm{C}$ contained in the supplementary feeds under study enhances gastric secretion, significantly increases the digestive capacity of pepsin, and controls the output of corticosterone by the adrenal glands, reducing its production and secretion. But, during stress, endogenous vitamin $\mathrm{C}$ is depleted in the adrenal glands, causing systemic secretion of this potent adrenal glucocorticoid. Adding vitamin $\mathrm{C}$ from an exogenous source helps in reducing the effects of stress and minimizes its negative impact on productivity (Abdin et al., 2017). It is essential in enhancing the metabolic processes, in particular, in removing reactive oxygen intermediates, as well as in the synthesis of collagen, adrenaline, and bile acids. It is known that cows can synthesize vitamin $\mathrm{C}$, and it is not an essential nutrient for dairy cows; there is evidence that vitamin $\mathrm{C}$ is associated with mastitis. Cows with mastitis have a lower concentration of vitamin $\mathrm{C}$ in the plasma and milk, and the clinical manifestation rate correlates with the magnitude of reduction in its concentration (Weiss and Hogan, 2007; Steinberg and Rucker, 2013; Skřivan et al., 2013).

Minerals are inorganic components that are included in fodder composition and in the livestock tissue structure. Their distribution in the body tissues and inside the cells is not random and uniform, which reflects their various functional roles. Minerals have no nutritional value, but they are catalysts for many biochemical reactions that proceed in the body and are inextricably linked to their form and state (Fisinin et al., 2009).

Nutritionists and livestock feeding specialists are faced with the task of finding effective natural sources of supplementary feeds. This is related to the fact that synthetic additives were criticized for their potentially detrimental effect on the food chain (Giannenas et al., 2018).

The currently available supplementary feeds include Laminaria, Pinus pumila, 
Chamaenerion Angustifolium L., and Urtica dioica, that contains almost all of the minerals required for normal animal life, including essential oils (Starikova, 2005; Steiner and Syed, 2015). Introduction of phytogenic (botanic) additives in diets can contribute to livestock productivity, mainly by improving feed conversion rate. Enhanced microbial activity in the small intestine may enhance the activity of digestive enzymes under the influence of the active substances of phytogenic supplements (Hafeez et al., 2016).

The main active ingredient of Laminaria is iodine that is an indispensable element in the livestock rations. Its deficiency is of particular importance in the poultry since it is more susceptible to thyroid disorders. There is evidence of a positive effect of thyroid hormones on the poultry genitals. This is due to the fact that during an intensive growth of gonads and puberty, the thyroid gland activity decreases slightly and increases again during the period of full egg production. The poultry that is distinguished by a medium and high activity of the thyroid gland has higher productivity at the adult stage and is more productive in progeny. Against the background of iodine deficiency in poultry, profound disorders occur in the protein, lipid, carbohydrate, and mineral metabolism, which leads to a decrease in feed digestibility and nutrient availability. As a result, the poultry health deteriorates, the egg production decreases, and the nutritional quality of eggs decreases (Spiridonov and Kislova, 2011). The positive effect of Algae on the thyroid function, the reproductive functions, the sperm quality, and the livestock productivity was also revealed (Fomichev et al., 2017). The content of iodine in products (such as eggs and milk) can be increased by including iodine-containing natural ingredients in the diet. lodine-enriched eggs and milk are a promising solution to preventing iodine deficiency in humans (Schöne and Rajendram, 2009; Makkar et al., 2016; Madeira et al., 2017; Opaliński, 2017; Schöne et al., 2017).

Recently, the feed industry has recognized the potential of vegetable components for various animal species. Phytogenic supplementary feeds containing essential oils (herbs and wild crops) combine bioactive ingredients and flavoring substances and are classified as "sensory additives" in accordance with European legislation. They improve the growth rate, nutrient availability, and the intestinal health of animals (Steiner and Syed, 2015).
The value of nutrients entering the body of animals as part of plant materials is that they have an organic form and a certain ratio. This allows them to easily assimilate and have an active effect on all the biological and physiological functions, including productivity and product quality (Starikova, 2005). The therapeutic and stimulating effect of the studied supplementary feeds on the livestock is also associated with their containing biologically active substances with various composition: alkaloids, coumarins, saponins, flavonoids, phytoncides, pectins, terpenoids, cardiac glycosides, essential oils, mucus, and organic acids, belonging to different classes of chemical compounds and having a different impact. The publications studied by me confirm the hypothesis about the positive influence of plant resources on the effectiveness of their use in livestock diets aiming to increase the metabolic rate, the productivity, the reproductive functions, the product quality, and the feed conversion rate. Our studies were carried out to determine the effect of input of nonconventional supplementary feeds vegetable made from sea furbelow (Laminaria), Pinus pumila, Lichenes, Chamaenerion Angustifolium $L$., and Urtica dioica on the productive qualities of cows and laying hens, the feed conversion rate, the product quality (milk and eggs), and the availability (use) of feed nutrients by laying hens and reproductive functions of cows. All the studies were conducted by a randomized method, including 2-5 levels of feeding. Three experiments were carried out on Ayrshire and Holstein cows in different physiological periods, and three experiments were performed on Hisex White cross laying hens in different age periods.

\subsection{Experimental studies}

\subsubsection{Studies of the supplementary feeding in cattle diet.}

Random schemes including 2 - 4 feeding levels were implemented in studying the supplementary vegetable feeds in cows' diet. Ayrshire and Holstein cows of different physiological phases were studied in terms of three experiments. For the experiment, the animals were selected in accordance with their breed, age, insemination term, and productivity.

The cows of the control group received the basic diet (BD) of feeding used in the farms, as well as the test group animals were fed with supplementary vegetable feeds according to schemes 1, 2 and 3.

Experimental scheme 1. Two groups of the Ayrshire cows (in milk period, the second 
lactation and stall-feeding period) were formed by the analog to pair matching method of eight animals each. The test group of animals received Laminaria supplementary feed in the amount of $200 \mathrm{~g}$ per animal per day in addition to the farm diet. The duration of the experiment was 82 days.

Experimental scheme 2. Four groups of the Ayrshire cows (the last two months in the period between lactations, two months of in milk period, the third lactation and stall-feeding period) were formed by the analog to pair matching method of eight animals each. In addition to the farm diet, the test group of animals received Laminaria supplementary feed in the amount of $50 \mathrm{~g}$ and Lichens supplementary feed in the amount of 40, 50 and $60 \mathrm{~g}$ per animal per day respectively. The duration of the experiment was 120 days, including 60 days of lactation.

Experimental scheme 3. Two groups of Holstein cows (from one to three months after calving, the second lactation and stall-feeding period) were formed by the analog to pair matching method of ten animals each. In addition to the farm diet, the test group of animals received creeping pine needle supplementary feed in the amount of $550 \mathrm{~g}$ per animal per day. The duration of the experiment was 94 days.

The preparation period of 10 days was defined before the experiment for the animals' adaption and accurate formation of the test groups. It was determined that there were no significant differences in live weight, productivity, and milk quality between the groups ( $P>0.05$ ). Feed intake was registered monthly during two adjacent days using the group method. Test milking was conducted once in ten days period, milk quality test (fat, protein) was conducted monthly. The effectiveness of the feeding was estimated in accordance with the expenditure of metabolic energy of the feed (MJ) per $1 \mathrm{~kg}$ of milk. The following criteria were estimated: the gross output of milk, quality of milk (fat, protein), feed energy expenditure per $1 \mathrm{~kg}$ of milk, the duration of the service period, conception rate and fertilization from the first insemination.

Feed conversion was estimated in accordance with the expenditure of metabolic energy of the feed for the production of $1 \mathrm{~kg}$ of milk with $3.6 \%$ of fat. The statistic results analysis included the calculation of the arithmetic average and errors of the average. The probability value $P<0.05$ was accepted as the statistically significant one, the fundamental differences between the groups were tested with Student criterion.

\subsubsection{Studies of the supplementary vegetable feeding in laying hens diet.}

Random schemes including 4 - 5 feeding levels were implemented in the scientific research of the supplementary vegetable feeds in laying hens diet in egg factories. Three experiments were conducted on Hisex White laying hens of different ages. The laying hens under analysis were divided into analog groups for 36 birds each. Six neighbor cages (with six birds each) were accepted as the experimental unit. All zoohygienic requirements were met in accordance with the laying hens' age and productive period. The test groups of birds followed the basic farm diet (BD) according to the specified age. Alongside with $\mathrm{BD}$, the test group of animals received supplementary vegetable feeds according to the schemes 4,5 , and 6 .

Experimental scheme 4. Four groups of the Hisex White laying hens aged from 38 to 64 weeks were analyzed. In addition to $\mathrm{BD}$, the test group of animals received Laminaria flour supplementary feed in the amount of $3.0 \%, 4.0 \%$, and $5.0 \%$. The duration of the experiment was 189 days.

Experimental scheme 5. Four groups of the Hisex White laying hens aged from 21 to 47 weeks were analyzed. The test group of animals received the supplementary feed of fireweed herbal flour in the amount of $2.0 \%, 3.0 \%$, and $4.0 \%$. Alongside with the herbal flour, the fourth test group of animals received brown seaweed flour in the amount of $1.0 \%$. The duration of the experiment was 175 days.

Experimental scheme 6. Five groups of the Hisex White laying hens aged from 23 to 40 weeks were analyzed. The following multicomponent supplementary feeds were included into the BD of the test groups: $2.0 \%$ of fireweed + $0.5 \%$ of creeping pine needle $+1.0 \%$ of Laminaria; $3.0 \%$ of fireweed $+0.5 \%$ of creeping pine needle $+0.5 \%$ of Laminaria; $2.0 \%$ of stinging nettle $+0.5 \%$ of creeping pine needle + $1.0 \%$ of Laminaria; $3.0 \%$ of stinging nettle $+0.5 \%$ of creeping pine needle $+0.5 \%$ of Laminaria. The second and the fourth groups were defined as the parallel to the substitution composition of the herbal flour. The duration of the experiment was 120 days.

The preparation period of 10 days was defined before the experiment for the laying hens' adaption and accurate formation of the test groups. It was determined that there were no significant differences in live weight and productivity between the groups $(P>0.05)$. Feed 
intake and eggs gathering were registered daily during the experiment. The effectiveness of the feeding (feed conversion) was estimated in accordance with the feed cost of $1 \mathrm{~kg}$ of the egg mass.

At the end of the research, 40 eggs from each group of birds were selected randomly for chemical compound and nutritive value tests. Carotenoid content of vitellus was identified in terms of all the experiments. In the context of the fourth experiment, additionally, the iodine content of the egg was identified. For that purpose, ten eggs from each group of birds were analyzed. The laying hens' feeding nutrient intake was analyzed in terms of physiological (balance) tests. For that purpose, six laying hens from each group were examined.

The following criteria were estimated: the nutritiousness and chemical compound of the feed, laying hens' live weight, gross egg production, egg production intensity, production of the egg mass, eggs quality, feed consumption, feed conversion, the utilization (digestion) of the feed nutritional substances.

The production of the egg mass was estimated by multiplying the egg mass on the egg production intensity.

The feed conversion was defined in accordance with the feed consumption in kilograms for the production of $1 \mathrm{~kg}$ of the egg mass.

The statistic results of the laying hens' productivity and eggs quality analysis included the calculation of the arithmetic average and errors of the average. The unilateral dispersion analysis was conducted to analyze the metabolism test results. The following criteria were estimated: the feed nitrogen utilization, protein, and fat digestibility, nitrogen-free extractive substance (NES). The probability value $P<0.05$ was accepted. The differences were tested with the Student criterion.

\section{RESULTS:}

\subsection{Productivity and efficiency of feeding}

The supplementary vegetable feeds implemented in lactating cows' diet influenced positively their productivity, quality of milk, and its consumer performance, as well as the cows' reproductive functions. The gross yield of milk during the experiment increased by $8.8-15.9 \%$ $(\mathrm{P}<0.05)$; the gross yield of milk of the basic fat content $(3.6 \%)$ and milk fat yield by $12.0-19.6 \%$ as well as fat and protein content in milk up to $0.4 \% \quad(P<0.05)$. The expenditure of metabolic energy of the feed for the production of $1 \mathrm{~kg}$ of milk with $3.6 \%$ of fat decreased to $14.5 \%$. The researches have shown that the use of natural supplementary feeds improves the cows' reproductive functions.

Experiment No. 1 has shown that the cows fed with Laminaria supplementary feed in the amount of $200 \mathrm{~g}$ had the service period shorter by 12.6 days $(P<0.05)$, the insemination index was by 1.0 lower than in control $(P<0.05)$, the conception rate was by $11 \%$ higher $(P<0.05)$. The decrease of the coefficient of variability (Cv, $\%$ ) of the service period and insemination index means the significant uniformity of these characteristics of the cows under analysis (Table 2).

The use of the Laminaria supplementary feed in the amount of $50 \mathrm{~g}$ and Lichens supplementary feed in the amount of 40,50 and $60 \mathrm{~g}$ (Experiment 2) provided the decrease of the service period for the test groups cows. The insemination index (the quantity of the inseminations for each fertilization), as well as the coefficient of variability $(\mathrm{Cv}, \%)$ of the service period and insemination index for the test groups' cows, were much lower than in control, while the $1^{\text {st }}$ insemination fertility became higher. The best results were shown by the cows of the $2^{\text {nd }}$ test group (Figure 1).

The use of the creeping pine needle supplementary feed in the lactating cows' diet in the amount of $550 \mathrm{~g}$ (experiment 3) contributed to the decrease of the service period by $10 \%$. The quantity of the inseminations decreased by 0.8 times for each fertilization case; the $1^{\text {st }}$ insemination fertility value increased by $20 \%$. The coefficient of variability (Cv, \%) of the service period decreased by 17.9 , and the insemination index decreased by 1.8

The researches have shown that the most effective form of the cows' diet nourishing is the use of Laminaria in the amount of $200 \mathrm{~g}$, which contributed to the gross yield of milk increase by $15.9 \%$ and feed cost decrease by $14.5 \%$ in relation to control.

The vegetable supplementary feeds introducing in laying hens' diet influenced positively their live weight that was significantly higher for all the tested laying hens $(\mathrm{P}<0.001)$ than in control but complied with the standards. The use of the new diet contributed to the gross egg production and egg mass yield increase as well as the intensity of the egg-laying capacity improvement. The best results of the production value improvement were indicated in Experiment 
5 (test group 4) where the supplementary feed of fireweed in the amount of $2.0 \%$ and Laminaria in the amount of $1.0 \%$ was introduced (Figure 2 ).

Feed cost of $1 \mathrm{~kg}$ of egg mass decreased by $5.1-15.4 \%$. The lowest feed cost was identified in experiment 4 test group 3, that received $4.0 \%$ Laminaria supplementary feeds (Table 3 ).

The studied supplementary feeds introduced in laying hens' diet influenced the production quality positively, namely: the average mass of the egg increased up to $7.2 \%$ $(P<0.05 \div P<0.001)$. That is $1.6 \%$ higher than in Krasnoschekova et al. research (2014). The analysis of the eggs from the test group laying hens showed the nutritional content improvement, namely the increase of the crude fat, crude protein, and NES $(P<0.05)$. The amount of carotenoid in the egg vitellus increased up to 1.6 times $(P<0.05 \div P<0.001)$. In the eggs from the laying hens from experiment 4 that were fed with the pure Laminaria supplementary feeds, the amount of iodine increased up to 8.6 times $(P<0.01 \div P<0.001)$. This exceeds the results obtained by Evtuhich and Lebedeva (2005), Antonyuk et al., (2010) in 3.3-5.7 (Figure 3, Table 4)

\subsection{The utilization of the nutritional substances of the laying hens' feed}

At the end of each experiment, the physiological (balance) tests were held to identify the quantity aspect of the laying hens' metabolism. For that purpose, six birds from each test groups were selected randomly. The record period lasted for three days. During this period, the amount of the consumed feed and excreted litter was accurately registered. The laboratory tests and the analysis of the obtained data and calculations contributed to the identification of the digestibility and utilization of the nutritional substances of the laying hens' feed. It was determined that in the test groups of laying hens, the metabolism intensification took place. The utilization (digestibility) of the feed nutritional substances was better than in test groups of birds, namely: nitrogen utilization to $13.6 \%$, protein utilization to $3.1 \%$, fat to $9.2 \%$ and NES to 6.3\%. (Table 5)

\section{DISCUSSION}

At present special attention is paid to the study of non-conventional vegetable components of the farm animals and poultry feed. The antibiotic, growth stimulating, antioxidant, antimicrobial, and anti-inflammatory activities were under analysis (Gustafson and Bowen,
1997). Schokker et al., (2017), Gheisar et al., (2017) declared that the substitution of the synthetic antibiotic in feeding farm animals and poultry for the natural vegetable supplementary feeds with antibiotic characteristics would exclude the negative influence of the antibiotics on the animals' organisms as well as the health of people who consume the agricultural products. Gheisar and Kim, (2017), Saki et al., (2014) defined the stimulating influence of the vegetable components with phytobiotic characteristics on the feed palatability that contributes to the increase in farm animals and poultry productivity.

Our research is devoted to studying the influence of non-conventional vegetable supplementary feeds on the cows and laying hens' productivity, production quality, feed conversion, the utilization of the nutritional substance by the laying hens' organisms and cows' reproductive function. The results of the research are confirmed by the specialists working with the farm animals and poultry diet enrichment with natural supplementary feeds that provides an increase in productivity, production quality, and feed conversion.

The introducing of the fir-tree and pine flour supplementary feeds in dairy cows' diet contributed to the shortening of the service period by $6.5-7.7 \%$ (Yegorov et al., 2007).

\section{Zharikov and Hurshkaynen (2011)} declared that the use of the fir-tree supplementary feeds contributed to the increase in the average daily milk yield of dairy cows by 1.5-3.5 and shortened the service period by 7 days on average. As a result of our research, the use of the creeping pine in the cows' diet provided the service period shortening by 11 days.

According to Dursenev et al., (2017), the use of the fir-tree needles supplementary feed influences positively on the animals' parturition and puerperium as well as the quantity and quality of the dairy products. The gargets appeared 2 times less in the test groups in relation to control. In conclusion, milk fat content in the test groups increased by $2.7-4.9 \%$, and protein content in milk increased by $6.9-11.4 \%$.

Studies by Naumova and Shukyurova (2011) proved that the use of Laminaria flour in newly-calved dairy cows' diet provides the increase in the average daily milk yield by $14.5 \%$ and fat content by $20.0 \%$.

Androsova (2000) claimed that the use of Laminaria in the cows' diet provides the 
avoidance of the milk-fever, gargets, and infectious interruption of pregnancy; in addition, the calving becomes easier. Milk productivity was improved by $10 \%$, milk fat content was increased by $1.0 \%$, besides the service period was shortened to 18 days, and the first insemination fertility increased up to $23 \%$; furthermore, the feed conversion improved to $25 \%$. Our experiments provided the improvement of milk productivity to $15.9 \%$.

Dedkova et al., (2007) stated that nowadays, the quality of the agricultural products and their ecological safety were of great importance, hence the agricultural products with low consumptive qualities were uncompetitive. Vegetable supplements and nettle, in particular, could be a substitute for synthetic antibiotics.

They do not cause negative effects on the poultry bodies as they contain the vitamins and mineral substances in available form. The use of nettle substances improves poultry resistance, livability, and productivity.

It was defined that the use of Laminaria supplementary feed in Hisex White laying hens' diet provided the improvement of the egg production intensity by $12.3 \%$ and egg weight increase to $5.7 \%$ (Krasnoschokova et al., 2014)

The research by Babuhadiya (2015) devoted to the use of Laminaria flour in laying hens' diet revealed that crude protein digestibility improved by $5.1 \%$, crude fat digestibility increased by $0.5 \%$, NES digestibility - by $1.1 \%$, egg production intensity - by $5.2-11.6 \%$ and egg mass yield - by $8.2 \%$ and $16.4 \%$.

Mammaeva (2002) identified that the use of Laminaria supplementary feed in Hisex White laying hens' diet provides the improvement of the egg production intensity by $11.8 \%$, egg weight increase by $10.3 \%$ and egg mass yield - by $10.7 \%$. As a result of our research, the use of Laminaria in hens' diet contributed to egg mass yield increase by $17.1 \%$.

According to Naumova (2017), the use of Laminaria supplementary feed in laying hens' diet conduced the improvement of protein digestibility to $2.6 \%$, fat digestibility increase to $2.4 \%$, egg production growth - by $5.9 \%$ and egg laying intensity by $4.8 \%$; in addition, the feed consumption for the production of $1 \mathrm{~kg}$ of egg mass decreased to $7.8 \%$.

The use of the composite supplementary feed that includes Laminaria determined the increase in egg production to $16.4 \%$ and egg laying intensity to $11.6 \%$. Feed protein digestibility increased to $11.8 \%$, and fat digestibility increased to $7.3 \%$ (Sharvadze et al., 2009).

Evtuhich et al., (2005) conducted a scientific experiment on industrial laying hens that received with Japanese Laminaria supplementary feed. The iodine content in the eggs increased in 2.4-2.6 times.

Antonyuk et al., (2010) in their research on the use of Laminaria in laying hens' diet confirmed that iodine content in the eggs of the test groups hens increased in 1.5 times. The experiment conducted according to our method provided this figure increase by 8.6 times.

The activation of metabolic processes in laying hens' bodies, the improvement of their productivity and eggs quality with the use of herbal flour in the diet are confirmed by a number of the researchers. Abou-Elkhair et al., (2018) revealed the positive influence of the vegetable (phytobiotic) supplements use in the laying hens' diet contributing to the egg laying intensity improvement to $9.1 \%$, egg mass yield growth to $16.7 \%$ and feed conversion ratio increase to $10.9 \%$

According to Saki et al., (2014) the use of the phytogenic supplementary feed in the laying hens' diet provided egg laying intensity improvement to $3.1 \%$, egg mass yield growth to $10.0 \%$ and feed conversion ratio increase to $1.8 \%$.

The use of the herbal flour in the laying hens' diet contributed to the increase of carotenoid content in the egg vitellus in 2.0-2.5 times and the amount of vitamins $A$ and $E$ growth in 1.2-2.1 times (Yegorov and Strukova, 2013).

The experiment conducted by Lukashenko and Velichko (2013) revealed that the use of the herbal flour in the laying hens' diet contributed to the increase of vitamin A content by $0.3-1.0 \mathrm{mcg} / \mathrm{g}$ and carotenoid content increase by $10.4-37.8 \mathrm{mcg} / \mathrm{g}$ in relation to control.

Manukyan $(2008,2012)$ studied the use of various doses of the herbal flour in hens' diet. The following indicators were determined: nitrogen utilization by the hens of the test groups improved by $1.3-2.4 \%$ in relation to control, fat digestibility raised by $1.4-2.9 \%$ and egg laying intensity enhanced by 2.9-8.7 pieces per hen; in addition, the carotenoid content in the egg vitellus increased in 2.0-2.5 times.

Our research revealed that the use of the herbal flour in laying hens' diet provides the egg mass yield growth to $17.6 \%$. The feed conversion 
ratio increased to $17 \%$, which exceeds similar figures in the analyzed works.

The research on the use of $2 \%$ stinging nettle flour in broiler chicken diet revealed that their live weight increases by $5.9 \%$, feed conversion enhances by $6.8 \%$ and livability raised by 3\% (Rabazanov, 2003).

The surveys of the stinging nettle use in broiler chicken diet confirmed its positive effect on the resistance of the body, livability and reproductive functions indicators namely: the average daily live weight gain growth by $5.3 \%$, broiler chicken live weight increased by $5.2 \%$ and birds livability improved by $4 \%$ (Dedkova and Avdyuhin, 2007).

The use of $1.0-5.0 \%$ of stinging nettle flour in broiler chicken diet provided the live weight increase by $3.4-3.5 \%$, livability enhanced by 2.0 $4.0 \%$, feed conversion by $3.2-5.1 \%$ and muscle mass of the egg mass yield growth by $2.2-4.4 \%$ (Ahmedhanova, 2003).

The use of $2 \%$ of stinging nettle flour in broiler chicken diet provided the live weight increase by $5.9 \%$, livability enhanced by $3.0 \%$, feed conversion by $6.8 \%$. Accumulation of vitamin $C$ in the liver of adult specimens increased by $0.41-2.04 \mathrm{mg} / \mathrm{g}$, in kidneys by 1.01 $1.96 \mathrm{mg} / \mathrm{g}$ and in adrenals by $0.64-2.31 \mathrm{mg} / \mathrm{g}$. As a result, the amount of vitamin $A$ in these organs increased that contributed to the improvement of the availability of feed biologically active substances, namely lysine availability increased by $12.3 \%$, methionine availability by $6.7 \%$ and cystine availability by $1.4 \%$ (Yegorov, 2014).

The definite balance of the biologically active substances in the supplementary vegetable feeds is of great importance for the living organisms. The authors confirmed that the use of vegetable supplements contributes to the improvement of the reproductive functions, the increase of productivity, and carotenoid content in the egg vitellus.

According to the results of our research, a number of patents for inventions providing the studied supplementary feeds implementation were obtained, namely:

- Patent ${ }_{(19)} \mathrm{RU}_{(11)} 2655210$ (13) "The ways to improve the quality and consumption properties of the table eggs";

- Patent ${ }_{(19)} R U_{(11)} \quad 2534307 \quad$ (13) "Composition of the biologically active supplementary feeds for laying hens, providing the productivity increase and eggs quality improvement";
- Patent (19) $\quad \mathrm{RU}_{(11)} \quad 2534266_{(13)}$ "Biologically active supplementary feeds for laying hens";

- Patent ${ }_{(19)} R U_{(11)} 2629993$ (13) "Laying hens' diet, providing the productivity increase and consumption properties of the production (eggs) improvement

- Patent ${ }_{(19)} R U_{(11)} 2599 \quad 564 \quad$ (13) "Supplementary feeds for cattle providing the immunomodulatory effect."

\section{CONCLUSIONS:}

The article reveals the results of the researches on the effects of introducing new nonconventional vegetable supplementary feeds in the diets of dairy cows and industrial laying hens. The composition of supplementary feeds included kelp, creeping pine needles, lichens, fireweed, and stinging nettle both in pure form and as a part of the component additives.

The authors have studied the effect of supplementary feeds on the productive qualities of cows and laying hens; quality of products (milk, eggs); nutrient digestibility (use) of laying hens and reproductive functions of cows; and have identified the economic efficiency of using these supplementary feeds by changing feed conversion ratio.

As a result, the most suitable doses were identified for introducing the (studied) supplementary feeds which significantly improve the productive qualities of cows and laying hens; quality of products (milk, eggs); feed conversion; nutrient digestibility (use) of laying hens and reproductive functions of cows. It was identified that the effectiveness of introducing the analyzed non-conventional vegetable supplementary feeds in the diets of dairy cows and industrial laying hens depends on the feed base (structure and nutritional value of the diet), reasonable selection of the components included into the diet and the schemes of their use. The required result can be achieved while strictly following the zoohygienic conditions for farm animals and poultry keeping.

\section{REFERENCES:}

1. Abdin, Z.; Khatoon, A..; Improving Performance Traits of Laying Hens with Vitamin C. In Egg Innovations and Strategies for Improvements, Hester, P.I. (ed.) Academic Press, Elsevier, 297-308, 2017, doi: 10.1016/B978-0-12-8008799.00028-7

2. Abdu-llah Al-Saif, A.A.; Abdel-Raouf, N., El-Wazanani H. A.; Arefl, A.; Antibacterial 
substances from marine algae isolated from Jeddah coast of Red Sea, Saudi Arabia. Saudi Journal of Biological Sciences, 2014, 21(1), 57-64, doi:10.1016/j.sjbs.2013.06.001.

3. Abou-Elkhair, R.; Ahmed, H.A.; Selim, S. Effects of black pepper (Piper Nigrum), turmeric powder (Curcuma Longa) and coriander seeds (Coriandrum Sativum) and their combinations as feed additives on growth performance, carcass traits, some blood parameters and humoral immune response of broiler chickens. Asian-Australas J Anim Sci, 2014, 27(6), 847-854. doi:10.5713/ajas.2013.13644

4. Abou-Elkhair, R.; Selim, S.; Hussein, E. Effect of supplementing layer hen diet with phytogenic feed additives on laying performance, egg quality, egg lipid peroxidation, and blood biochemical constituents. Animal Nutrition, 2018, 4(4), 394-400. doi:10.1016/j.aninu.2018.05.009

5. Ahmedhanova, R. Non-conventional supplement feeds for chicken. Russian Livestock, 2003, 4, 25.

6. Al-Amoudi, O.A.; Mutawie, H.H.; Patel, A.A.; Blunden, G. Chemical composition and antioxidant activities of Jeddah corniche algae. Saudi Arabia. Saudi Journal of Biological Sciences, 2009. 16(1), 23-29. doi:/10.1016/j.sjbs.2009.07.004.

7. Androsova, L.F. The use of supplement feed containing sea furbelow (Laminaria) and fish residues in farm animals and poultry diet. In Actual problems of biology in livestock science: Abstracts. Borovsk, 2000, 39-40.

8. Antonyuk, N.; Naumova, L; Bogatskaya M. Poultry farming innovations in Khabarovsk Krai. Russian Livestock, 2010, 10, 21-22.

9. Babuhadiya, K.R.; Doctor thesis, Far Eastern State Agrarian University, Russia, 2015.

10. Balina, K.; Romagnoli, F.; Blumberga, D. Chemical Composition and Potential Use of Fucus Vesiculosus from Gulf of Riga. Energy Procedia, 2016, 95, 43-49, doi:10.1016/j.egypro.2016.09.010.

11. Bate, P.N.N.; Orock, E.A.; Nyongbel, K. D.; Babiaka, S.B.; Ngemenya, M.N. In vitro activity against multi-drug resistant bacteria and cytotoxicity of lichens collected from Mount Cameroon. Journal of King Saud University-Science, 2018, doi:10.1016/j.jksus.2018.09.001
12. Bazes, A.; Silkina, A.; Douzenel, P.; Faÿ, F.; Kervarec, N.; Morin, D.; Berge, J-P.; Bourgougnon, $\mathrm{N}$. Investigation of the antifouling constituents from the brown alga Sargassum muticum (Yendo) Fensholt. J Appl Phycol, 2009, 21, 395. doi:10.1007/s10811-008-9382-9.

13. Dedkova, A.I.; Avdyuhin, A.S. The use of vegetable components for the improvement of livability and productivity of broiler chicken. Zootechnics, 2007, 8, 19-20.

14. Dobbelaar, P.; Bouwstra, R.J.; Goselink, R.M.A.; Jorritsma, R.; van den Borne, J.J.G.C.; Jansen, E.H.J.M. Effects of vitamin $E$ supplementation on and the association of body condition score with changes in peroxidative biomarkers and antioxidants around calving in dairy heifers. Journal of Dairy Science, 2010, 93(7), 3103-3113, doi:10.3168/jds.20092677.

15. Dursenev, M.S; Filatov, A.V. Productive quality of cows at use of bio-supplement VERVA in dry period. Agricultural Science Euro-North-East, 2017, 5(60), 43-46.

16. Evtuhich, N.; Lebedeva, I. Egg. Iodine deficiency overcoming. Poultry farming, 2005, 7, 22-23.

17. Feng, S.; Zeng, W.; Luo, F. Antibacterial activity of organic acids in aqueous extracts from pine needles (Pinus massoniana Lamb). Food Science and Biotechnology, 2010, 19(1), 35-41, doi.org/10.1007/s10068-010-0005-2.

18. Fisinin, V.I.; Egorov, I.A.; Okolelova, T.M.; Imangulov, Sh.A. Scientific basis of poultry feed. Sergiev Posad: Russian Research and Technological Institute of Poultry, 73-262, 2009.

19. Fomichev, Y.P.; Nikanova, L.A. Increasing of the reproductive properties of boar semen while using organic iodine in feeding. Russ. Agricult. Sci., 2017, 43 (5), 419-422.

doi:10.3103/S1068367417050056.

20. Freysdottir, J.; Omarsdott, S.; Ingolfsdottir, K.; Vikingsson, A.; Olafsdottir, E.S. In vitro and in vivo immunomodulating effects of traditionally prepared extract and purified compounds from Cetraria islandica. International Immunopharmacology, 2008, 8(3), 423430. doi:10.1016/j.intimp.2007.11.007

21. Gheisar, M.M.; Kim, I.H. Phytobiotics in poultry and swine nutrition review. Ital $J$ 
Anim Sci, 2017, 17, 92-99, doi:10.1080/1828051X.2017.1350120

22. Giannenas, I.; Bonos, E.; Christaki, E.; Florou-Paneri, P. Oregano: A Feed Additive with Functional Properties. Therapeutic Foods. Handbook of Food Bioengineering, 2018, 8, 179-208. Academic Press. doi:1016/B978-0-12811517-6.00006-4.

23. Gonzalez-Esquerra, R.; Leeson, S. Alternatives for enrichment of eggs and chicken meat with omega-3 fatty acids. Canadian Journal of Animal Science, 2001, 81(3), 295-305. doi:10.4141/A00092

24. Goodband, B.; Tokach, M.; Dritz, S.; De Rouchey, J.; Woodworth, J. Practical starter pig amino acid requirements in relation to immunity, gut health and growth performance. Journal of Animal Science and Biotechnology, 2014, 5, 12, doi:10.1186/2049-1891-5-12.

25. Goryacheva, M.M. Alternative to antibiotics. Bird and poultry products, 2013, 1, 16-19.

26. Gustafson, R.H., and R.E. Bowen. Antibiotic use in animal agriculture. J Appl Microbiol., 1997, 83(5), 531-541. doi:10.1046/j.1365-2672.1997.00280.x

27. Hafeez, A.; Männer, K.; Schieder, C.; Zentek, J. Effect of supplementation of phytogenic feed additives (powdered vs. encapsulated) on performance and nutrient digestibility in broiler chickens. Poultry Science, 2016, 95(3): 622-629. doi:10.3382/ps/pev368

28. Hernandez, F.; Madrid, J.; Garcia, V.; Orengo, J.; Megias, M. Influence of two plant extracts on broilers performance, digestibility, and digestive organ size. Poult Sci., 2004, 8, 169-174. doi:10.1093/ps/83.2.169

29. Huyghebaert, G.; Ducatelle, R; Van, F. Immerseel. An update on alternatives to antimicrobial growth promoters for broilers. Vet J., 2011, 187(2), 182-188. doi:10.1016/j.tvjl.2010.03.003

30. Ingolfsdottir, K.; Jurcic, K.; Fischer, B.; Wagner, $H$. Immunologically active polysaccharide from Cetraria islandica. Planta Med., 1994, 60(6): 527-531. https://doi.org/10.1055/s-2006-959564

31. Krasnoschokova, T.A.; Prostokishin, A.S.; Babuhadiya, K.R.; Nimaeva, V.Ts.; Ischenko, O.Yu.; Plotnikov, N.B. The efficiency of introducing Laminaria with micronutrients into the laying hens' diet. Zootechnics, 2014, 1, 17-18.

32. Lantto, T.A., Shikov, A.N., Pozharitskaya, O.N.; Makarov, V.G.; Tikhonov, V.P.; Hiltunen, R.; Raasmaja, A. Chemical composition, antioxidative activity and cell viability effects of a Siberian pine (Pinus sibirica Du Tour) extract. Food Chemistry, 2009, 112(4), 936-943, doi:10.1016/j.foodchem.2008.07.008

33. Lemesheva, M. Aminoacidic birds' feed. Russian Livestock, 2006, 11, 25-27.

34. Lukashenko, V.S.; Velichko, O.A. The functional eggs production: time requirement. Bird and Poultry Products, 2013, 4: 28-30.

35. Madeira, M.S.; Cardoso, P.; Lopes, P.A.; Coelho, D.; Afonso, C.; Bandarra, N.M.; Prates, J.A.M. Microalgae as feed ingredients for livestock production and meat quality: A review. Livestock Science, 2017, 205, 111-121, doi:10.1016/j.livsci.2017.09.020.

36. Makkar, H.P.S.; Tran, G.; Heuzé, V.; Giger-Reverdin, S.; Lessire, M.; Lebas, F.; Ankers, P. Seaweeds for livestock diets: A review. Animal Feed Science and Technology, 2016, 212, 1-17. doi:10.1016/j.anifeedsci.2015.09.018

37. Mammaeva, T.V.; Doctor Thesis. Ecological and biological substantiation of Laminaria supplement feed use in hens' diet. in Biology. Khabarovsk. Institute of Water and Environmental Problems, Far Eastern Branch, RAS, 2002.

38. Manojlović, N.; Ranković, B.; Kosanić, M.; Vasiljević, P; Stanojković, T. Chemical composition of three Parmelia lichens and antioxidant, antimicrobial and cytotoxic activities of some their major metabolites. Phytomedicine, 2012, 19 (13), 1166-1172. doi:10.1016/j.phymed.2012.07.012.

39. Manukyan, V. Herbal flour in broiler chicken diet. Poultry farming, 2008, 2, 1011.

40. Manukyan, V. Valuable natural feed. Russian Livestock, 2012, 4, 19-20.

41. Matanjun, P.; Mohamed, S.; Mustapha, N.M.; Muhammad, K.; Ming, C.H. Antioxidant activities and phenolics content of eight species of seaweeds from north Borneo. J Appl Phycol., 2008, 20, 367-373. doi:10.1007/s10811-007-9264-6.

42. Meimandipour, A.; Nouri Emamzadeh, A.; Soleimani, A. Effects of nanoencapsulated aloe vera, dill and nettle root extract as feed antibiotic 
substitutes in broiler chickens. Arch. Anim. Breed., 2017, 60 (1), 1-7. doi:10.5194/aab-60-1-2017, 2017.

43. Moubayed, N.M.S.; Jawad, Al Houri, H.; Al Khulaifi, M.M.; Al Farrari, D.A. Antimicrobial, antioxidant properties and chemical composition of seaweeds collected from Saudi Arabia (Red Sea and Arabian Gulf). Saudi Journal of Biological Sciences, 2017, 24(1), 162-169. doi:10.1016/j.sjbs.2016.05.018

44. Mulder, I.E.; Schmidt, B.; Lewis, M.; Delday, M.; Stokes, C.R.; Bailey, M.; Aminov, R.I.; Gill, B.P.; Pluske, J.R.; Mayer, C.D.; Kelly D. Restricting microbial exposure in early life negates the immune benefits associated with gut colonization in environments of high microbial diversity. PLoS One, 2011, 6(12), e28279. doi:10.1371/journal.pone.0028279

45. Mulder, I.E.; Schmidt, B; Stokes, C.R.; Lewis M.; Bailey M.; Aminov R.I.; Prosser J.I.; Gill, B.P.; Pluske J.R.; Mayer C.D.; Musk C.C.; Kelly D. Environmentally-acquired bacteria influence microbial diversity and natural innate immune responses at gut surfaces. BMC Biol., 2009, 7, 79 . doi:/10.1186/1741-7007-7-79

46. Müller, K. Pharmaceutically relevant metabolites from lichens. Applied Microbiology and Biotechnology, 2001. 56 (1-2), 9-16. doi:10.1007/s002530100684

47. Naumova, L.; Shukyurova, E. The studying of Laminaria use in Far Eastern cattle diet. Zootechnics, 2011, 11, 6-7.

48. Naumova, L.I. Supplemented feed of land and sea genesis in laying hens' diet. Poultry farming, 2017, 12: 20-22.

49. Niewold, T.A. The nonantibiotic antiinflammatory effect of antimicrobial growth promoters, the real mode of action? A hypothesis. Poult Sci., 2007, 86(4): 605609, doi:10.1093/ps/86.4.605

50. Opaliński, S. Supplemental lodine. In Egg Innovations and Strategies for Improvements, Hester P.I. (ed.) Academic Press, Elsevier, 393-402, 2017, doi:10.1016/B978-0-12-800879-9.00037-8

51. Podterob, A.P. Chemical composition of lichens and their medical applications. Pharmaceutical Chemistry Journal, 2008. 42 (10), 582-588. doi:10.1007/s11094009-0183-5.

52. Pompeu, M.A.; Cavalcanti, L.F.L.; Toral F.L.B. Effect of vitamin E supplementation on growth performance, meat quality, and immune response of male broiler chickens: A meta-analysis. Livestock Science, 2008, 208, 5-13. doi:10.1016/j.livsci.2017.11.021

53. Prakash, U.N.; Srinivasan, K. Beneficial influence of dietary spices on the ultrastructure and fluidity of the intestinal brush border in rats. Br J Nutr., 2010, 104, 31-39. doi:10.1017/S0007114510000334

54. Rabazanov, N. Doctor Thesis, The studying of the nettle flour use in the broiler chicken diet., Sergiev Posad. 2003.

55. Rogachev, A.D.; Salakhutdinov N.F. Chemical Composition of Pinus sibirica (Pinaceae). Chemistry and Biodiversity, 2015, $12 \quad$ (1), 1-53. doi:10.1002/cbdv.201300195

56. Saki, A.A.; Aliarabi, H.; Siyar, S.A.H.; Salari, J.; Hashemi M. Effect of a phytogenic feed additive on performance, ovarian morphology, serum lipid parameters and egg sensory quality in laying hen. Vet Res Forum, 2014, 5, 287293.

57. Schäfers, S.; Soosten, D.; Meyer, U.; Drong, C.; Frahm, J.; Tröscher, A.; Pelletier, W.; Sauerwein, H.; Dänicke S. Influence of conjugated linoleic acids and vitamin $\mathrm{E}$ on biochemical, hematological, and immunological variables of dairy cows during the transition period. Journal of Dairy Science, 2018, 101 (2), 1585-1600. doi:10.3168/jds.2017-13071.

58. Schokker, D.; Jansman, A.J.; Veninga, G.; De Bruin, N.; Vastenhouw, S.A.; de Bree, F.M. Bossers, A., Rebel, J.M.; Smits M.A. Perturbation of microbiota in one-day old broiler chickens with antibiotic for 24 hours negatively affects intestinal immune development. BMC Genomics, 2017, 18(1), 241-254, doi:10.1186/s12864-0173625-6

59. Schöne, F. lodine in Farm Animals. In: Comprehensive Handbook of lodine: Nutritional, Biochemical, Pathological and Therapeutic Aspects; Burrow, G.N.; Preedy, V.R.; Rajendram, R.; Schöne, F.; Watson; R. (eds.), Academic Press, Elsevier, 151-170. (2009), doi:10.1016/B978-0-12-374135-6.000169.

60. Schöne, F.; Spörl, K.; Leiterer, M. lodine in the feed of cows and in the milk with a view to the consumer's iodine supply. Journal of Trace Elements in Medicine 
and Biology, 2017, 39, 202-209., doi:10.1016/j.jtemb.2016.10.004.

61. Sharvadze, R.; Babuhadiya, K.; Litvinenko, N. Seafood in feeding industrial and parent flock chickens. Far Eastern Agrarian Bulletin, 2009, 4(12), 4247, doi:10.24411/1999-6837-2009-00069

62. Shrestha, G.; Clair, L.L.St.; O'Neill, K.L. The immunostimulating role of lichen polysaccharides: a review. Phytotherapy Research, 2015, 29(3), 317-322, doi:10.1002/ptr.5251

63. Skřivan, M.; Marounek, M.; Englmaierová, M.; Skřivanová, V. Influence of dietary vitamin $C$ and selenium, alone and in combination, on the performance of laying hens and quality of eggs. Czech J. Anim. Sci., 2013, 58(2): 91-97. doi:10.17221/6619-CJAS

64. Spiridonov, A.; Kislova, O. Eggs and chicken meat enrichment with iodine. Poultry Farming, 2011, 3, 21-25.

65. Starikova, N. Biologically active additives. Condition and problems: monograph. Khabarovsk, 2005, RPCKSUEL.

66. Steinberg, F.M.; Rucker, R.B. Vitamin C. In: Encyclopedia of Biological Chemistry; Lennarz, W.J.; Lane, M.D. (eds.). Academic Press, Elsevier, 530-534, 2013, doi:10.1016/B978-0-12-378630-2.00092$\mathrm{X}$.

67. Steiner, T.B.; Syed, B. Phytogenic Feed Additives in Animal Nutrition. In: Medicinal and romatic Plants of the World. Medicinal and Aromatic Plants of the World, Máthé Á. (ed.), Springer, Dordrecht., 2015, 1, 403-423, doi:10.1007/978-94-017-9810520.

68. Surai, P.F.; Fisinin, V.I.; Karadas, F. Antioxidant systems in chick embryo development. Part 1. Vitamin E, carotenoids and selenium. Animal Nutrition, 2016, 2(1), 1-11., doi:10.1016/j.aninu.2016.01.001.

69. Suray, P. How to improve the nutritiousness of eggs. Combined Feeds, 2010, 6, 95-96.

70. Tajodini, M.; Saeedi, H.; Moghbeli, P. Use of black pepper, cinnamon and turmeric as feed additives in the poultry industry.
World's Poultry Science Journal, 2015, 71(1), 175-183, doi:10.1017/S0043933915000148.

71. Weiss, W.P.; Hogan, J.S. Effects of Dietary Vitamin C on Neutrophil Function and Responses to Intramammary Infusion of Lipopolysaccharide in Periparturient Dairy Cows. Journal of Dairy Science, 2007, 90(2), 731-739, doi:10.3168/jds.S00220302(07)71557-6.

72. Windisch, W.; Schedle, K.; Plitzner, C.; Kroismayr, A. Use of phytogenic products as feed additives for swine and poultry. $J$ Anim Sci., (2008). 8, E140-E148, doi:10.2527/jas.2007-0459

73. Yegorov, I.; Strukova, G. The use of the herbal flour in Poultry farming. Poultry Farming, 2013, 8, 2-6.

74. Yegorov, I.A. Valuable poultry feed. Poultry Farming, 2014, 6, $22-24$.

75. Yegorov, I.A.; Andrianova, E.N.; Prisyazhnaya, L.M.; Kuchin, A.V.; Hurshkaynen, T.V. The use of Verv drug and fir tree needles flour in combined feed for broiler chicken. Bird and Poultry Products, 2007, 6, 39-41.

76. Zeng, W-C.; Zhang, Z.; Jia, L-R. Antioxidant activity and characterization of antioxidant polysaccharides from pine needle (Cedrus deodara). Carbohydrate Polymers, 2014, 108, 58-64, doi:10.1016/j.carbpol.2014.03.022.

77. Zhao X.; Xue C.H.; Li, B.F. Study of antioxidant activities of sulfated polysaccharides from Laminaria japonica. J Appl Phycol, 2008, 20. 431, doi:10.1007/s10811-007-9282-4.

78. Zhao, Y., Weaver, A. C., Fellner, V., Payne, R.L.; Kim, S.W. Amino acid fortified diets for weanling pigs replacing fish meal and whey protein concentrate: Effects on growth, immune status, and gut health. Journal of Animal Science and Biotechnology, 2014, 5, 57., doi:10.1186/2049-1891-5-57.

79. Zharikov, Ya.A.; Hurshkaynen, T.V. The influence of the fir tree supplemented feeds on the dairy cows' productivity. Zootechnics, 2011, 5, 9-11. 
Table 1. The content of basic active ingredients in the components under study (in $100 \mathrm{~g}$ of air-dry substance)

\begin{tabular}{|c|c|c|c|}
\hline \multicolumn{4}{|c|}{ Laminaria flour } \\
\hline Indices & Contained & Indices & Contained \\
\hline \multicolumn{4}{|c|}{ Essential amino acids, \% } \\
\hline Lysine & 0.39 & Histidine & 0.28 \\
\hline Methionine & 0.18 & Glycine & 0.40 \\
\hline Threonine & 0.41 & Isoleucine & 0.23 \\
\hline Tryptophan & 0.07 & Leucine & 0.47 \\
\hline Arginine & 0.56 & Phenylalanine & 0.45 \\
\hline Valine & 0.36 & Tyrosine & 0.27 \\
\hline \multicolumn{4}{|c|}{ Minerals: } \\
\hline Manganese, mg & 1.05 & Copper, mg & 0.83 \\
\hline Zinc, mg & 1.45 & Selenium, mg & 0.02 \\
\hline Iron, mg & 60.5 & lodine, mg & 43.3 \\
\hline \multicolumn{4}{|l|}{ Vitamins: } \\
\hline $\mathrm{E}, \mathrm{mg} / \mathrm{g}$ & up to 650 & $\mathrm{~B}_{2}, \mathrm{mcg} / \mathrm{g}$ & up to 23.08 \\
\hline $\mathrm{B}_{1}, \mathrm{mcg} / \mathrm{g}$ & up to 4.60 & $\mathrm{C}, \mathrm{mg} / \mathrm{g}$ & 26.00 \\
\hline Carotenoids, mcg/g & 20.32 & & \\
\hline \multicolumn{4}{|c|}{ Other active ingredients: } \\
\hline$\%$ to protein substances & & Chondrin, mg \% & up to 190 \\
\hline Fatty acids & 0.65 & Taurine, mg \% & up to 220 \\
\hline Alginic acids & 40.00 & Citrulline, mg \% & up to 240 \\
\hline Mannitol & 28.00 & & \\
\hline Fucoidin & 5.00 & & \\
\hline \multicolumn{4}{|c|}{ Pinus pumila flour } \\
\hline Indices & Contained & Indices & Contained \\
\hline \multicolumn{4}{|c|}{ Essential amino acids, \% } \\
\hline Lysine & 0.09 & Histidine & 0.12 \\
\hline Threonine & 0.16 & Leucine & 0.23 \\
\hline Tryptophan & 0.25 & Tyrosine & 0.24 \\
\hline Arginine & 0.15 & & \\
\hline \multicolumn{4}{|c|}{ Minerals: } \\
\hline Sodium, $\mathrm{g}$ & 0.054 & Phosphorus, g & 0.19 \\
\hline Calcium, $\mathrm{g}$ & 0.27 & Iron, g & 0.04 \\
\hline \multicolumn{4}{|c|}{ Vitamins: } \\
\hline $\mathrm{B}_{1}, \mathrm{mg}$ & 19.1 & $\mathrm{E}, \mathrm{mg}$ & up to 540 \\
\hline $\mathrm{B}_{2}, \mathrm{mg}$ & 5.9 & $\mathrm{C}, \mathrm{mg}$ & up to 4850 \\
\hline $\mathrm{B}_{3}, \mathrm{mg}$ & 27.7 & $\mathrm{H}, \mathrm{mg}$ & 0.15 \\
\hline $\mathrm{B}_{5}, \mathrm{mg}$ & 141.9 & $\mathrm{~B}_{\mathrm{C}}, \mathrm{mg}$ & 8.0 \\
\hline $\mathrm{B}_{6}, \mathrm{mg}$ & 2.0 & Carotenoids, mg \% & 31.8 \\
\hline \multicolumn{4}{|c|}{ Other active ingredients: } \\
\hline Glycolipids, \% & 14.1 & Aspartic acid, mg \% & up to 187 \\
\hline Phospholipids, \% & 5.6 & Glutamic acid, mg \% & up to 326 \\
\hline Chlorophyll, mg \% & 493.5 & Stearins, mg \% & 10.0 \\
\hline \multicolumn{4}{|c|}{ Chamaenerion angustifolium L. flour } \\
\hline Indices & Contained & Indices & Contained \\
\hline \multicolumn{4}{|c|}{ Essential amino acids, \% } \\
\hline Lysine & 0.68 & Histidine & 0.29 \\
\hline Methionine & 0.20 & Glycine & 0.74 \\
\hline Threonine & 0.67 & Isoleucine & 0.66 \\
\hline Tryptophan & 0.24 & Leucine & 1.06 \\
\hline Arginine & 0.72 & Phenylalanine & 0.68 \\
\hline Valine & 0.76 & Tyrosine & 0.55 \\
\hline \multicolumn{4}{|c|}{ Minerals: } \\
\hline Calcium, g & 1.27 & Potassium, g & 2.03 \\
\hline Phosphorus, g & 0.51 & Sodium, g & 0.09 \\
\hline \multicolumn{4}{|c|}{ Vitamins: } \\
\hline
\end{tabular}




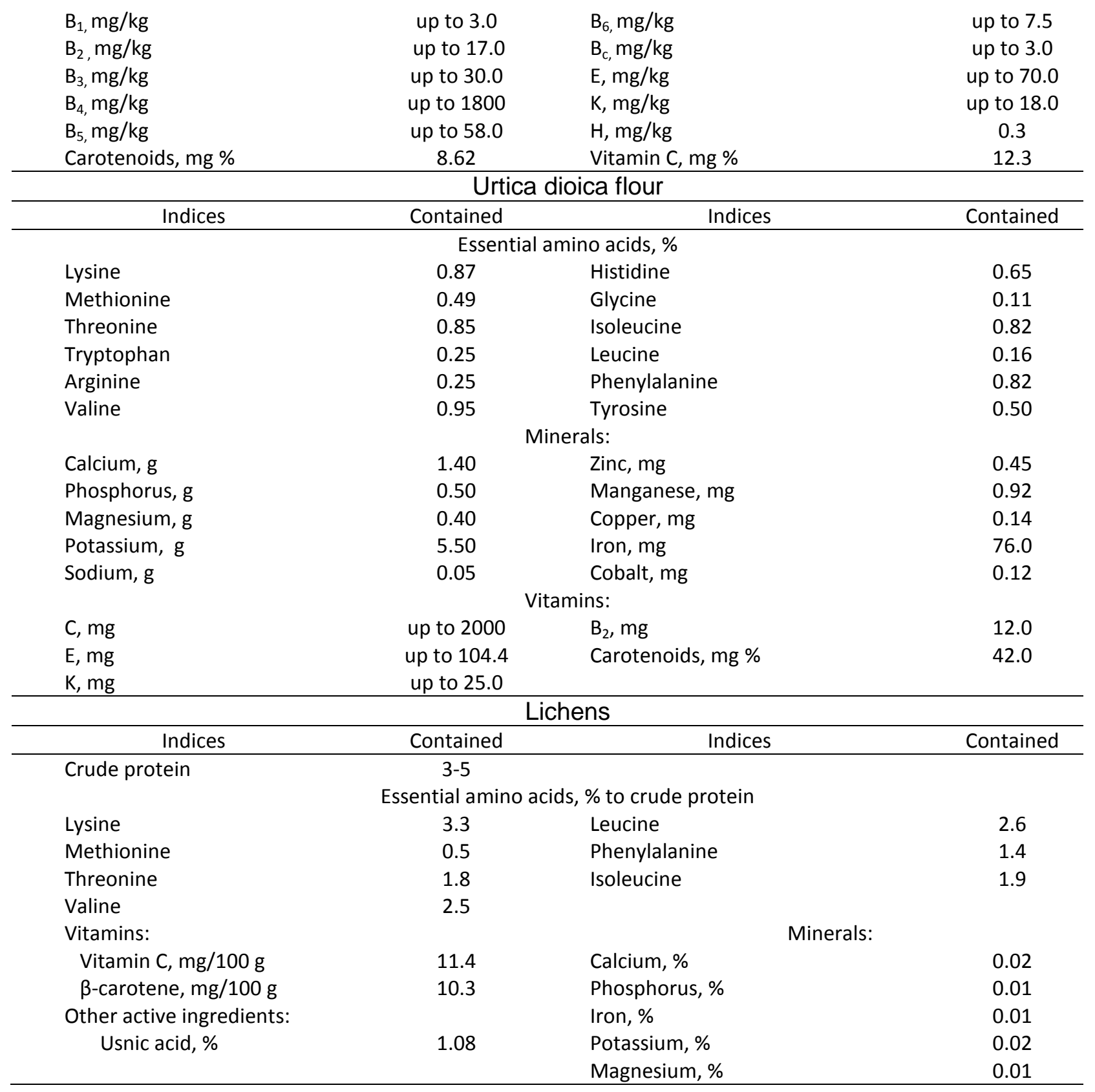


Table 2. The cows' productive functions characteristics

\begin{tabular}{|c|c|c|c|c|c|}
\hline \multirow{2}{*}{ Groups } & \multicolumn{2}{|c|}{ Service period, days } & \multicolumn{2}{|c|}{ Insemination index } & \multirow{2}{*}{$\begin{array}{c}1^{\text {st }} \text { insemination } \\
\text { fertility }(\%)\end{array}$} \\
\hline & $M \pm m$ & $\mathrm{Cv}, \%$ & $M \pm m$ & $\mathrm{Cv}, \%$ & \\
\hline \multicolumn{6}{|l|}{ Experiment 1} \\
\hline Control & $92.3 \pm 10.2$ & 20.3 & $2.4 \pm 0.04$ & 12.6 & 66.7 \\
\hline Test & $79.7 \pm 6.3$ & 15.3 & $1.4 \pm 0.02$ & 10.5 & 77.8 \\
\hline \multicolumn{6}{|l|}{ Experiment 2} \\
\hline Control & $119.3 \pm 13.5$ & 33.9 & $3.0 \pm 0.53$ & 50.0 & 62.5 \\
\hline $1^{\text {st }}$ test & $101.4 \pm 10.4$ & 20.2 & $2.5 \pm 0.32$ & 36.8 & 75.0 \\
\hline $2^{\text {nd }}$ test & $89.7 \pm 6.5$ & 15.8 & $2.25 \pm 0.25$ & 31.5 & 87.5 \\
\hline $3^{\text {rd }}$ test & $98.6 \pm 7.2$ & 17.0 & $2.7 \pm 0.36$ & 37.4 & 62.5 \\
\hline \multicolumn{6}{|l|}{ Experiment 3} \\
\hline Control & $120.1 \pm 4.8$ & 36.5 & $2.6 \pm 0.05$ & 12.6 & 60.0 \\
\hline Test & $109.1 \pm 2.6$ & 18.6 & $1.8 \pm 0.03$ & 10.8 & 80.0 \\
\hline
\end{tabular}

Table 3. The productive value of the laying hens

\begin{tabular}{|c|c|c|c|c|c|}
\hline \multirow[b]{2}{*}{ Values } & \multicolumn{5}{|c|}{ Groups } \\
\hline & $1^{\text {st }}$ control & $2^{\text {nd }}$ test & $3^{\text {rd }}$ test & $4^{\text {th }}$ test & $\begin{array}{l}5^{\text {th }} \\
\text { test }\end{array}$ \\
\hline \multicolumn{6}{|l|}{ Experiment 4} \\
\hline $\begin{array}{l}\text { Live weight at the end of the } \\
\text { experiment, } g\end{array}$ & 1702.6 & 1785.6 & 1790.5 & 1789.0 & - \\
\hline Gross egg production, pcs. & 4425 & 4639 & 4773 & 4456 & - \\
\hline $\begin{array}{l}\text { The intensity of the egg-laying capacity, } \\
\%\end{array}$ & 78.24 & 84.24 & 85.58 & 83.48 & - \\
\hline Egg mass, total, kg & 225.64 & 251.03 & 264.29 & 233.13 & - \\
\hline Feed conversion coefficient & 2.83 & 2.47 & 2.38 & 2.58 & - \\
\hline \multicolumn{6}{|l|}{ Experiment 5} \\
\hline $\begin{array}{l}\text { Live weight at the end of the } \\
\text { experiment, } g\end{array}$ & 1718.4 & 1758.3 & 1770.8 & 1773.6 & - \\
\hline Gross egg production, pcs. & 5425 & 5642 & 5835 & 5902 & - \\
\hline $\begin{array}{l}\text { The intensity of the egg-laying capacity, } \\
\%\end{array}$ & 86.45 & 89.56 & 92.62 & 93.68 & - \\
\hline Egg mass, total, kg & 275.0 & 299.7 & 323.4 & 334.2 & - \\
\hline Feed conversion coefficient & 2.74 & 2.60 & 2.43 & 2.33 & - \\
\hline \multicolumn{6}{|l|}{ Experiment 6} \\
\hline $\begin{array}{l}\text { Live weight at the end of the } \\
\text { experiment, } g\end{array}$ & 1603.3 & 1670.3 & 1658.6 & 1680.0 & 1661.4 \\
\hline Gross egg production, pcs. & 3571 & 3759 & 3728 & 3860 & 3848 \\
\hline $\begin{array}{l}\text { The intensity of the egg-laying capacity, } \\
\%\end{array}$ & 82.66 & 87.01 & 86.30 & 89.35 & 89.07 \\
\hline Egg mass, total, kg & 166.96 & 192.68 & 188.52 & 201.84 & 195.76 \\
\hline Feed conversion coefficient & 3.10 & 2.69 & 2.75 & 2.57 & 2.65 \\
\hline
\end{tabular}


Table 4. Eggs quality

\begin{tabular}{lccccc}
\hline \multicolumn{1}{c}{ Values } & \multicolumn{5}{c}{ Groups } \\
\cline { 2 - 6 } & $1^{\text {st }}$ control & $2^{\text {nd }}$ test & $3^{\text {rd }}$ test & $4^{\text {th }}$ test & $\begin{array}{c}5^{\text {th }} \\
\text { test }\end{array}$ \\
\hline Experiment 4 & & & & & \\
Average weight of egg, g & 63.0 & 65.5 & 65.9 & 64.1 & - \\
Crude fat, \% & 8.1 & 8.5 & 8.4 & 8.4 & - \\
Crude protein, \% & 11.2 & 12.0 & 12.0 & 11.7 & - \\
NES, \% & 2.3 & 2.5 & 2.7 & 2.4 & - \\
Carotin, mg/g & 4.34 & 4.36 & 5.02 & 5.10 & - \\
lodine, mg \% & 80.54 & 117.04 & 319.48 & 692.41 & - \\
\hline Experiment 5 & & & & & \\
Average weight of egg, g & 61.3 & 65.7 & 64.8 & 65.1 & - \\
Crude fat, \% & 7.0 & 7.2 & 6.9 & 7.2 & - \\
Crude protein, \% & 12.1 & 12.3 & 12.1 & 12.2 & - \\
NES, \% & 2.4 & 2.4 & 2.5 & 2.1 & - \\
Carotin, mg/g & 4.53 & 4.57 & 4.97 & 5.02 & - \\
\hline Experiment 6 & & & & & \\
Average weight of egg, g & 59.0 & 59.8 & 59.74 & 60.5 & 60.3 \\
Crude fat, \% & 8.6 & 9.1 & 9.0 & 9.0 & 9.0 \\
Crude protein, \% & 11.3 & 11.3 & 11.6 & 11.6 & 11.7 \\
NES, \% & 2.9 & 3.0 & 3.0 & 3.2 & 3.0 \\
Carotin, mg/g & 9.1 & 10.0 & 10.6 & 14.0 & 14.4 \\
\hline
\end{tabular}

Table 5. The utilization of the feed nutritional substances

\begin{tabular}{lccccc}
\hline \multirow{2}{*}{ Values } & \multicolumn{5}{c}{ Groups } \\
\cline { 2 - 6 } & $1^{\text {st }}$ control & $2^{\text {nd }}$ test & $3^{\text {rd }}$ test & $4^{\text {th }}$ test & $\begin{array}{c}5^{\text {th }} \\
\text { test }\end{array}$ \\
\hline Experiment 4 & & & & & \\
Feed nitrogen utilization, \% & 40.50 & 50.96 & 47.67 & 47.97 & - \\
Protein digestibility, \% & 87.82 & 90.47 & 90.65 & 90.52 & - \\
Fat digestibility, \% & 67.37 & 69.52 & 69.67 & 69.51 & - \\
NES digestibility, g & 74.16 & 75.91 & 75.66 & 74.85 & - \\
\hline Experiment 5 & & & & & \\
Feed nitrogen utilization, \% & 35.19 & 48.78 & 42.77 & 43.66 & - \\
Protein digestibility, \% & 89.60 & 91.22 & 91.09 & 91.20 & - \\
Fat digestibility, \% & 67.73 & 68.11 & 69.79 & 69.51 & - \\
NES digestibility, g & 69.83 & 76.13 & 72.82 & 73.28 & - \\
\hline Experiment 6 & & & & & \\
Feed nitrogen utilization, \% & 35.97 & 47.59 & 44.48 & 46.80 & 44.72 \\
Protein digestibility, \% & 88.70 & 91.53 & 91.61 & 91.77 & 91.42 \\
Fat digestibility, \% & 55.64 & 61.97 & 64.82 & 61.81 & 61.01 \\
NES digestibility, g & 71.79 & 74.67 & 74.46 & 75.66 & 75.26 \\
\hline
\end{tabular}




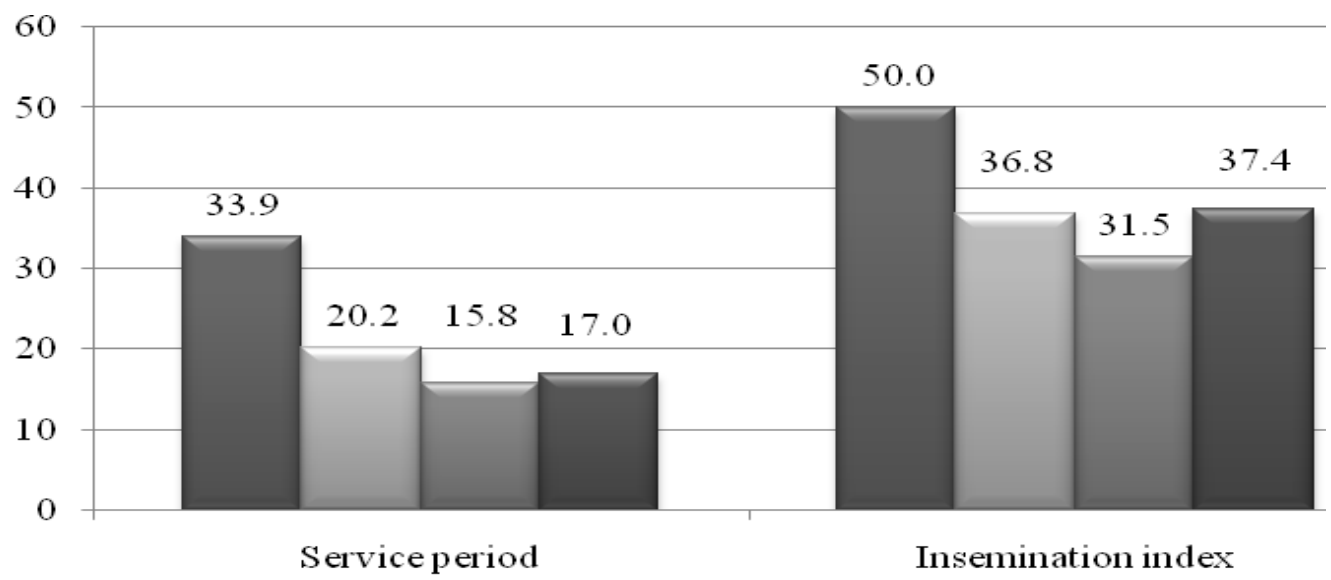

$\square$ Control group $\square 1$ st test group $\square 2$ nd test group $\quad \square$ 3rd test group

Figure 1. The coefficient of variability of the cows' reproductive function in Experiment 2, \%

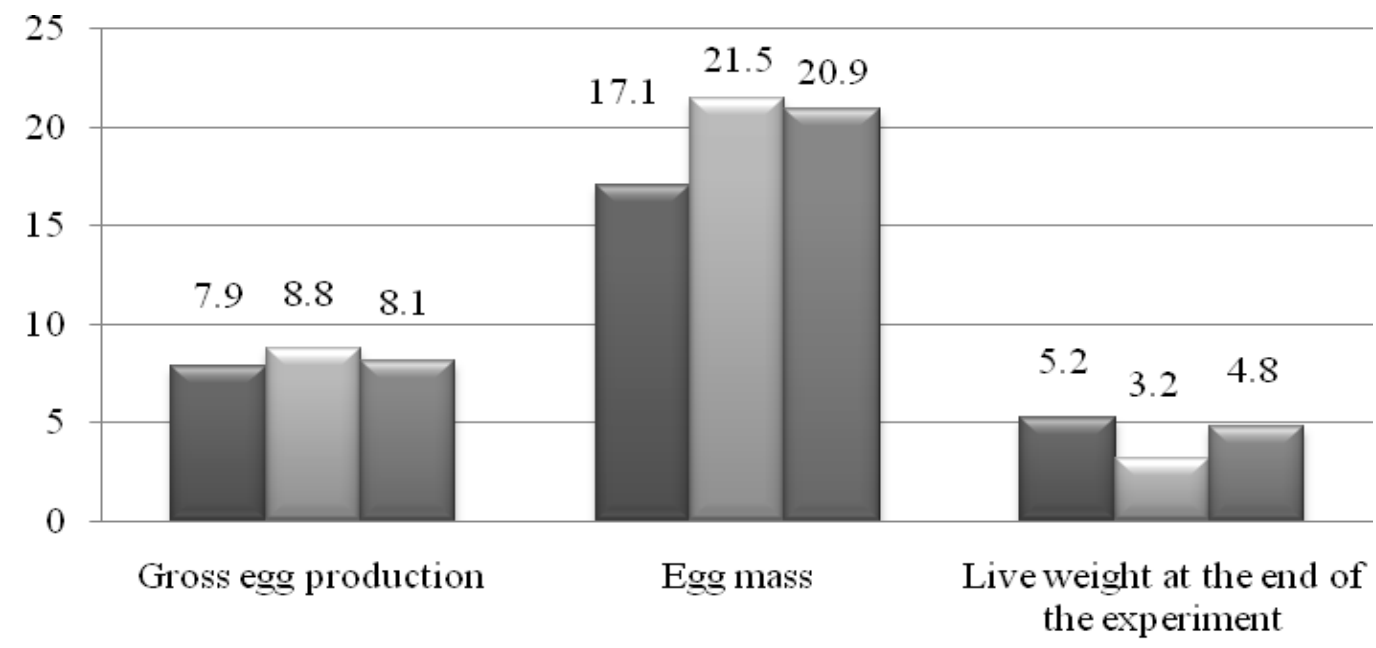

$\square$ Experiment $4 \square$ Experiment $5 \square$ Experiment 6

Figure 2. The productive value of the laying hens' growth, \% (in relation to control)

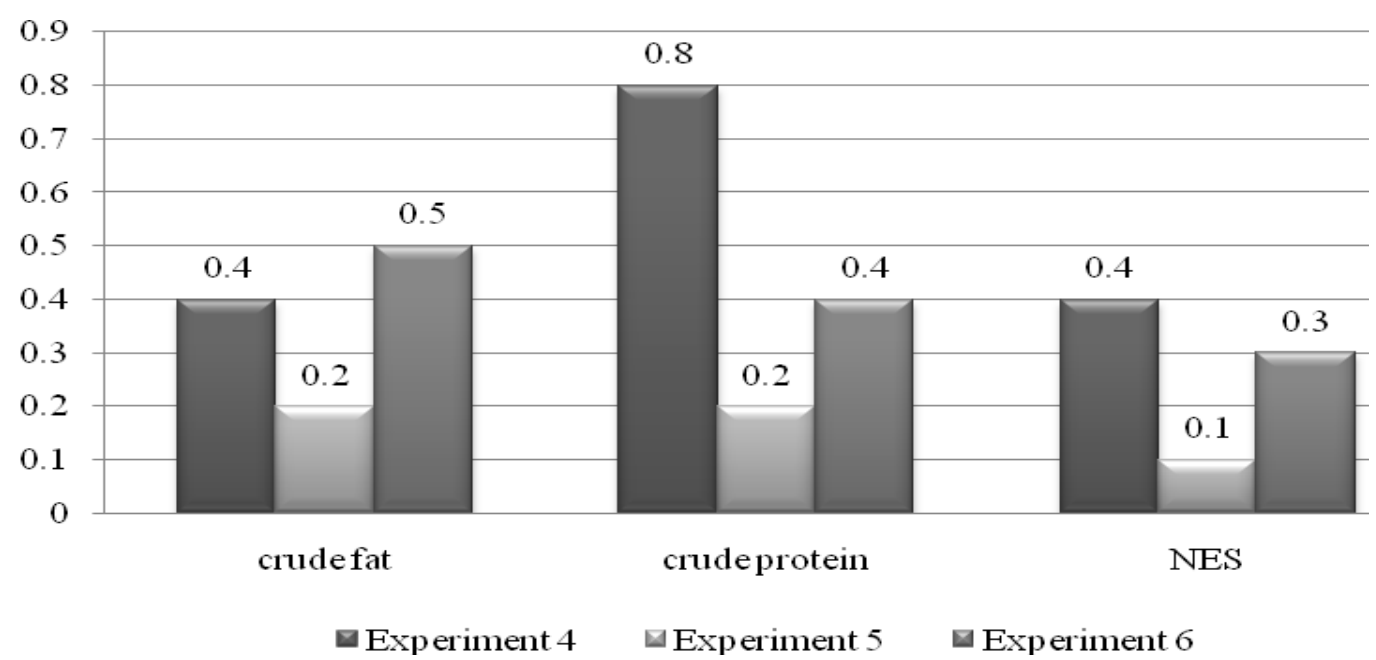

Figure 3. Eggs nutritiousness improvement in relation to control, \% 